\title{
Portale społecznościowe jako narzędzie promocji i public relations w społeczeństwie informacyjnym Perspektywy rozwoju
}

\begin{abstract}
Social networking sites as promotion and public relations tools in the information society - development perspectives

The article aims to familiarize with the development of the Internet as a means of communication and promotion tool as well as public relations in contemporary global society and the society of electronic media. The share of electronic channels in interpersonal communication is constantly growing, becoming a dominant way of media communication in the world. This does not mean that it will be the only way of communication, but it should be noted that it will be the dominant one. The article attempts to approximate the issue of the development of new media in terms of statistics and quantity, but also because of the demographics and geographical location of users. It shows the structures and possibilities as well as potential ways of media development in the future. The statistics come from research centers mainly from the United States of America. The analysis covers general issues of social media, mainly social media portals and their scale of impact on the global society. It should be noted that the attitude of enterprises to society has changed. Thanks to better data, more detailed advertising parameters and a growing user base, social media is one of the ways to invest. Adaptation of social media by older people is constantly growing - which means that more companies can benefit from ads targeted directly to this group. When choosing a social network to advertise, make sure that the adoption of social media by the target age group is high.
\end{abstract}

Key words: contemporary media, the Internet, Public Relations, media promotion, social communication, media communication 


\section{Wstęp}

Żyjemy w epoce społeczeństwa informacyjnego, w którym dostęp do informacji za pomocą Internetu jest fundamentalnym i kluczowym sposobem komunikacji zarówno w relacjach osobistych, jak i biznesowych. Artykuł ma na celu przybliżenie problematyki rozwoju Internetu jako środka komunikacji i narzędzia promocji oraz public relations we współczesnym społeczeństwie globalnym oraz społeczeństwie mediów elektronicznych. Udział kanałów elektronicznych w komunikacji międzyludzkiej stale rośnie, stając się powoli dominującym sposobem komunikacji medialnej na świecie. Nie oznacza to oczywiście, iż będzie to jedyny sposób komunikacji. Artykuł podejmuje próbę przybliżenia problematyki rozwoju nowych mediów pod względem statystyczno-ilościowym, ale także ze względu na demografię i położenie geograficzne użytkowników. Ukazuje struktury i możliwości oraz potencjalne drogi rozwoju mediów w przyszłości. Dane statystyczne pochodzą z ośrodków badawczych, głównie ze Stanów Zjednoczonych. Analiza obejmuje ogólne zagadnienia dotyczące mediów społecznościowych, głównie portali społecznościowych i ich skali oddziaływania na społeczeństwo ogólnoświatowe ${ }^{1}$.

\section{Rozwój mediów społecznościowych}

Należy zauważyć, iż od powstania komputera do upowszechnienia się tego urządzenia wśród zwykłych obywateli wykorzystujących go do celów prywatnych upłynęło stosunkowo niewiele czasu. Końcowe lata XX wieku przyniosły ogromną rewolucję technologiczną, która wpływa niewątpliwie na wszystkie aspekty życia współczesnego człowieka.

Definicja multimediów Walerego Pisarka to określenie mediów łączących kanały nadawania, kody oraz sposoby kształtowania komunikatów wielu mediów. Należy zauważyć, że wyróżnikiem mediów elektronicznych, w szczególności Internetu, jest jego interaktywność. Mass media to środki komunikowania masowego, a więc wszelkie urządzenia, które w komunikowaniu masowym służą transmisji a właściwie dyfuzji informacji ${ }^{2}$. Jak zauważył Jay Botler, nowa technologia przeważnie podporządkowuje sobie poprzednią. Komputery same nie wykonują pracy z własnej inicjatywy ${ }^{3}$. Ważnym aspektem komputera w porównaniu z zespołem ludzkim jest to, iż w maszynie tej poszczególne elementy systemu pracują niemal

${ }^{1}$ M. Szpunar, Społeczna przestrzeń internetu. Internet jako medium komunikacji społecznej, [w:] Media - komunikacja - zdrowie. Wyzwania - szanse - zagrożenia, red. B. Aouli, Toruń 2008, s. 31.

2 W. Pisarek, Słownik terminologii medialnej, Kraków 2006, s. 108-173.

${ }^{3}$ J. Bolter, Komputer: maszyna i narzędzie, [w:] Nowe media w komunikacji społecznej XX wieku, red. M. Hopfinger, Warszawa 2005, s. 357-366. 
idealnie, wyklucza się niedoskonałość i wolną wolę jednostki jako składnika zespołu ${ }^{4}$. Przewaga Internetu nad innymi środkami komunikacji masowej polega na tym, iż dzięki sieci można nawiązywać kontakty na całym świecie. Internet stał się najbardziej demokratycznym medium na świecie.

Autorzy książki Edukacja medialna ${ }^{5}$ zauważają, iż jeszcze nigdy nie przekazywano tak wiele, tak szybko, tak licznym, za tak niewiele. Kultura masowa jest kulturą dominującą w społeczeństwie masowym, biorąc pod uwagę ciągłą produkcję i konsumpcję. Jej istotnym elementem jest publiczność mediów, charakteryzująca się homogenicznością wytworów kultury i wzorów korzystania $\mathrm{z}$ nich ${ }^{6}$. Internet jest $\mathrm{w}$ dzisiejszych czasach jednym z najważniejszych mediów dzięki swoim cechom i właściwościom. Jest to technologia wykorzystująca komputery, ma ona hybrydowy, wyspecjalizowany i elastyczny charakter. Ma ogromny potencjał interaktywności, pełni funkcje zarówno prywatne, jak i publiczne. Charakteryzuje się niskim stopniem regulacji oraz wzajemnymi powiązaniami na bardzo wysokim stopniu. Internet jest wszechstronny i nieoznaczony przestrzennie, jest dostępny dla obywateli, zarówno dla nadawców, jak i odbiorców komunikatów. Ta elastyczność i wszechstronność czyni Internet bardzo potężnym medium7.

\section{Promocja w mediach społecznościowych}

Promocja powinna być procesem szeroko odbieranym i łatwo przyswajanym. Stosując narzędzia promocji, należy zwrócić szczególną uwagę na cele, aby dostosować narzędzia do realizacji strategii i taktyki marketingowej. Skuteczność promocji mierzy się wszakże jej efektywnością osiąganą na rynku. Narzędzia promocyjne wspomagane są często przez stosowanie technik public relations. W ich skład wchodzą między innymi kontakty ze środkami masowego przekazu, lobbing, doradztwo, seminaria naukowe, wystawy, konkursy, jubileusze, gazetki, periodyki i wiele innych pokrewnych elementów. Public relations można określić także jako przemyślane, zamierzone, intencjonalne i zorganizowane działanie podmiotów w celu wpływania na tworzenie opinii i wizerunku wśród publiczności, grupy docelowej. Inaczej rzecz ujmując, jest to promocja wizerunku firmy, kreowanie pozytywnych kontaktów i stosunków przedsiębiorstw z otoczeniem, a także kształtowanie korzystnego obrazu medialnego i wzbudzanie zainteresowania

${ }^{4}$ W. Hills, Superkomputery i ewolucja, [w:] Nowe media w komunikacji społecznej XX wieku, red. M. Hopfinger, Warszawa 2005, s. 430-439.

${ }^{5}$ J. Gajda, S. Juszczyk, Edukacja medialna, Toruń 2004, s. 225-230.

6 Tamże, s. 225-230.

${ }^{7}$ D. McQuaid, Teoria komunikowania masowego, Warszawa 2012, s. 58-60. 
wśród odbiorców ${ }^{8}$. To także zespół celowo zorganizowanych działań zapewniających systematyczne komunikowanie się ze środowiskiem oraz kreowanie, promowanie, podtrzymywanie pozytywnego wizerunku przedsiębiorstwa, czyli opinii o jego uczciwości i dobrej woli9. Zadaniem PR jest wzbudzenie uwagi, by inni uczestnicy rynku byli zainteresowani kooperacją z przedsiębiorstwem, a w szczególności: nabywali jego dobra i korzystali z jego usług, udzielali firmie kredytów, ułatwiali firmie tworzenie nowych inwestycji, współpracowali $\mathrm{w}$ dziedzinie produkcji, dystrybucji i dostaw ${ }^{10}$.

Środki przekazu stosowane w public relations to między innymi wiadomości rozpowszechniane przez firmę lub przez inne podmioty, sympozja, spotkania oraz konferencje, uroczystości oraz obchody rocznic, dofinansowanie imprez różnego rodzaju, akcje na rzecz zdrowia, bezpieczeństwa, ochrony środowiska, zwiedzanie obiektów przedsiębiorstwa, materiały informacyjne rozpowszechniane przez firmę, środki identyfikacji wizualnej ${ }^{11}$.

\section{Publicity jako narzędzie promocji}

Publicity to każda informacja lub notatka związana z działalnością firmy, która $\mathrm{w}$ następstwie działań public relations ukazuje się w mediach nieodpłatnie i wywołuje rozgłos.

Public relations jest elementem szeroko rozumianej promocji, jest zbiorem środków, za pomocą których przedsiębiorstwo komunikuje się z rynkiem, czyli przekazuje informacje o swojej działalności lub konkretnych produktach i usługach $^{12}$. To cały system działań, których celem jest rozpoznanie i trafienie w potrzeby potencjalnych klientów i zachęcenie ich do nabycia danego dobra, a także wytworzenie pozytywnego wizerunku produktu i firmy oraz utrwalanie go ${ }^{13}$. To komunikowanie się przedsiębiorstwa $\mathrm{z}$ nabywcami przez wzajemne przekazywanie informacji ułatwiających wymianę produktów. Promocja jest najbardziej widocznym przejawem aktywności rynkowej z punktu widzenia konsumenta.

${ }^{8}$ L. Pokrzycka, Promocja i public relations w społeczeństwie informacyjnym. Studia przypadków, Lublin 2011, s. 7-9.

9 E. Michalski, Marketing, Warszawa 2004, s. 370.

10 Ibidem, s. 370-371.

${ }^{11}$ H. Mruk, Podstawy marketingu, Poznań 1999, s. 239.

12 E. Michalski, dz. cyt., s. 299.

13 T. Kramer, Podstawy marketingu, Warszawa 2003, s. 143. 


\section{Promocja - element strategii}

Natomiast sama promocja jest jednym z elementów szeroko rozumianego marketingu. Według Philipa Kotlera marketing jest to „proces społeczny i zarządczy, dzięki któremu konkretne osoby i grupy otrzymują to, czego potrzebują i pragną osiągnąć przez tworzenie, oferowanie i wymianę posiadających wartość produktów"14. Natomiast Garry Barret postrzega marketing jako proces związany głównie z zarządzaniem wyborem. Brytyjski Chartered Institute of Marketing definiuje pojęcie marketingu jako „proces zarządzania odpowiedzialny za określenie, przewidywanie i zaspokajanie z zyskiem wymagań nabywców”" Według Amerykańskiego Stowarzyszenia Marketingu (AMA) jest to proces planowania i urzeczywistniania koncepcji, cen, promocji oraz dystrybucji idei, dóbr i usług w celu doprowadzenia do wymiany satysfakcjonującej jednostki i organizacje. Większość cytowanych definicji marketingu zwraca uwagę na to, że marketing jest procesem związanym z zarządzaniem przedsiębiorstwem. Marketing w ujęciu ekonomiczno-historycznym podkreśla ewolucję, jaką przeszedł rynek, od zorientowania na produkcję do zorientowania na rynek, od rynku ukierunkowanego na produkcję seryjną i masowe wytwarzanie produktów po rynek ukierunkowany na wielkość sprzedaży i potrzeby konsumenta ${ }^{16}$. Marketing w ujęciu klasycznym jest to działanie ukierunkowane przede wszystkim na zysk. Nabywca tworzy rynek przedsiębiorstwa. Przedsiębiorca oddziałuje na rynek za pomocą różnego rodzaju narzędzi. System decyzyjny opiera się na planowaniu przez zinstytucjonalizowane podmioty przyszłych zamierzeń i działań. Planowanie, koordynacja i kontrola wszystkich działań ukierunkowane są na aktualne i potencjalne rynki zbytu. Szerokie ujęcie marketingu zwraca szczególną uwagę na system społeczny, w którym cały czas zachodzą procesy zakupu, przez co konsumenci zaspokajają swoje pragnienia ${ }^{17}$. Obejmuje on wszystkie rodzaje wymiany dóbr i usług między uczestnikami rynku. Odnosi się także do instytucji i jednostek działających na zasadach non profit. „Dzięki takiemu ujęciu nastawienie na klientów znalazło zastosowanie nie tylko w przedsięwzięciach nastawionych na zysk finansowy, ale w realizacji inicjatyw społecznych czy też politycznych, w których zyskiem jest korzyść społeczna lub polityczna"18.

Koncepcja marketingowa zakłada, iż sposobem do osiągnięcia jej celów jest określenie potrzeb i wymagań rynków docelowych, dostarczenie pożądanego zadowolenia w sposób bardziej wydajny i skuteczny niż konkurenci. Koncepcja

\footnotetext{
${ }^{14}$ P. Kotler, Marketing, Warszawa 1994, s. 6.

15 T. Ambler, Marketing od A do Z, Kraków 1999, s. 129.

16 Tamże.

17 J. Altkorn, dz. cyt., s. 28.

${ }^{18}$ P. Kotler, dz. cyt., s. 14-16.
} 
marketingowa opiera się na czterech głównych założeniach: rynku docelowym, potrzebach klienta, marketingu skoordynowanym i rentowności. Koncepcja marketingu społecznego opiera się na założeniu, że poza działaniami zaspokajającymi potrzeby wybranej grupy klientów koniecznie są również działania, które przynoszą korzyść społeczeństwu ${ }^{19}$.

Reklama i public relations zaczynają swoją misję od skupiania się na uczuciach odbiorców, aby znaleźć klienta lub zmienić jego relacje i postawę lub myślenie. Do niedawna reklama była narzędziem informowania odbiorców o poszukiwaniu klientów. Współcześnie reklama staje się bardziej ukierunkowana, opłacalna i nastawiona na wyszukiwanie. Google i inne wyszukiwarki oferują unikalne możliwości reklamy, aby uzyskać dostęp do klientów na całym świecie za stosunkowo niski budżet $\mathrm{w}$ porównaniu $\mathrm{z}$ innymi formami promocji. Public relations był instrumentem do opracowywania i skutecznej komunikacji z opinią publiczną. Współcześnie PR obejmuje obszary związane z przewodzeniem i zmienianiem poglądów oraz myślenia publicznego. Na przykład Facebook, LinkedIn, Twitter i inne media społecznościowe umożliwiają całodobowe komunikowanie się ze społeczeństwem, ale również zajmowanie się kluczowymi kwestiami dostępu do nowych grup społecznych i stale angażują, zmieniają ich myślenie, postawy oraz charakter.

\section{Media społecznościowe w danych statystycznych}

Dane statystyczne ukazują tempo rozwoju i udział mediów społecznościowych w rynku. Dane za rok 2016 pokazują, iż 97\% dorosłych w wieku 16-64 lat twierdzi, że odwiedziło lub korzystało z sieci społecznościowej w ciągu ostatniego miesiąca. Użytkownicy Internetu mają średnio siedem kont społecznościowych (dla porównania - w roku 2012 średnia liczba kont wynosiła trzy). Ponad połowa dorosłych online (56\%) korzysta $\mathrm{z}$ więcej niż jednej z pięciu platform mediów społecznościowych. Globalnie Facebook pozostaje największą siecią społecznościową (84\% wszystkich użytkowników Internetu), YouTube natomiast odwiedza większy odsetek internautów (87\% użytkowników).

Około 79\% użytkowników internetu (68\% wszystkich dorosłych) korzysta z Facebooka. W roku 2016 na całym świecie istniało ponad 1,79 miliarda aktywnych użytkowników Facebooka, co stanowiło 16-procentowy wzrost w stosunku do roku 2015. Około1,8 miliarda ludzi logowało się na Facebook codziennie (dane na wrzesień 2016 r.), co stanowiło wzrost o $17 \%$ z rokiem 2015. Prawie $85 \%$ aktywnych użytkowników Facebooka znajdowało się poza USA i Kanadą. Z danych na wrzesień 2016 r. wynika, iż liczba użytkowników mobilnych tej aplikacji wynosiła

19 Tamże. 
1,66 miliarda, co stanowiło wzrost o $20 \%$ w porównaniu z rokiem 2015. Przeciętny użytkownik Facebooka miał 130 znajomych. Ten najpopularniejszy serwis ma na chwilę obecną jedną z największych baz danych na świecie. Wzbogaca się on o 500000 nowych użytkowników i sześć nowych profili co sekundę. Szacuje się także, że na tym portalu istnieje 270 milionów fałszywych profili. Najpopularniejszą stroną jest strona główna Facebooka z liczbą 207, 7 mln polubień. Na Facebooku jest 60 milionów aktywnych stron biznesowych. Ma on 5 milionów aktywnych reklamodawców. Przekierowania z tego portalu stanowią 53,1\% logowań społecznościowych tworzonych przez konsumentów, którzy logują się w aplikacjach i witrynach wydawców i marek. W czwartki i piątki zaangażowanie jest o $18 \%$ wyższe. Co 60 sekund na Facebooku publikowano 510000 komentarzy, aktualizowano 293000 statusów i przesyłano 136000 zdjęć $^{20}$.

Ponad 2 miliony reklamodawców regularnie korzysta z Facebooka, aby promować swoją działalność. Co miesiąc na stronach Facebooka publikuje się 2,5 miliarda komentarzy. Największy ruch na tym portalu odbywa się między godziną 13 a 15. Przedstawiane statystyki źródłowe prezentują serię danych liczbowych. Dla osób działających w branżach biznesowych oraz dla naukowców znajomość takich statystyk jest niezbędna, aby zobaczyć skalę zjawiska, jak i stopień oraz szybkość rozwoju poszczególnych rozwiązań. Umożliwia to opracowanie strategii i zaplanowanie na przykład wydatków przez osoby korzystające z sieci społecznościowych w celach biznesowych.

Według danych z października 2017 r. ogólna liczba ludności na świecie wynosiła około 7,6 miliarda. Dostęp do Internetu miało 3,5 miliarda użytkowników. Istniało 3,03 miliarda aktywnych użytkowników mediów społecznościowych. Około 91\% marek detalicznych korzystało z dwóch lub więcej kanałów tych mediów. Blisko $81 \%$ wszystkich małych i średnich firm korzystało z jakiejś platformy internetowej. Pojedynczy użytkownik Internetu ma założonych średnio 7,6 kont w wyżej wymienionych mediach. Liczba użytkowników social media zwiększyła się o 121 milionów w okresie od drugiego do trzeciego kwartału 2017 r. Co 15 sekund rejestruje się nowy użytkownik. Facebook Messenger i Whatsapp obsługują 60 miliardów wiadomości dziennie. Liczba użytkowników innych mediów społecznościowych pod koniec trzeciego kwartału 2017 r., wyglądała następująco:

- 4Chan: 27,7 miliona,

- Airbnb: 150 milionów użytkowników,

- Facebook: 2,072 miliarda użytkowników,

- Flickr: 90 milionów użytkowników,

${ }^{20}$ https://www.brandwatch.com/blog/96-amazing-social-media-statistics-and-facts-for-2016/ [dostęp: 20.01.2018]. 
- Google+: 111 milionów użytkowników,

- Instagram: 800 milionów użytkowników,

- LinkedIn: 500 milionów użytkowników,

- MySpace: 15 milionów użytkowników,

- Peryskop: 10 milionów użytkowników,

- Pinterest: 200 milionów użytkowników,

- Reddit: 234 miliony użytkowników,

- Snapchat: 178 milionów użytkowników,

- Twitter: 330 milionów użytkowników,

- Wechat: 1,12 miliarda użytkowników,

- Weibo: 600 milionów użytkowników,

- WhatsApp: 900 milionów użytkowników,

- Youtube: 1,5 miliarda użytkowników ${ }^{21}$.

Natomiast statystyki biznesowe dotyczące mediów społecznościowych w roku 2015 przedstawiały się następująco. Media społecznościowe uzyskały szacunkowo 8,3 miliarda USD przychodu za reklamę. Niemal 40 miliardów dolarów wydano na reklamę w sieciach społecznościowych w 2016 r. Około 38\% organizacji planuje wydać więcej niż $20 \%$ całkowitego budżetu reklamowego na kanały mediów społecznościowych w 2016 r., co stanowi wzrost o 13\% w stosunku do roku wcześniejszego. Tylko 20 firm z listy największych firm rankingu Fortune 500 faktycznie angażuje się w kontakt z klientami na Facebooku, a 83\% na Twitterze. Osoby w wieku 55-64 lat są dwa razy bardziej skłonne do angażowania się w marketingowe akcje internetowe niż osoby w wieku 28 lat lub młodsze. $Z$ danych wynika, że $78 \%$ osób, które piszą skargi i reklamacje za pośrednictwem Twittera, czeka na odpowiedź około godzinę. Na platformie do zarządzania stronami internetowymi WordPress publikowanych jest 99,8 milionów wpisów na blogach w każdym miesiącu.

Trzy najważniejsze sposoby komunikowania marketingowego w Internecie to: treści w mediach społecznościowych (83\%), blogi (80\%) i biuletyny e-mailowe (77\%). Około 89\% marketerów B2B używa strategii content marketingu. Facebook notuje obecnie 8 miliardów średnich dziennych wyświetleń wideo z 500 milionów użytkowników. Użytkownicy Snapchata generują również 8 miliardów wyświetleń filmów dziennie. Amerykańscy dorośli spędzają średnio godzinę i 16 minut każdego dnia, oglądając wideo na urządzeniach cyfrowych. Około $78 \%$ osób ogląda filmy online co tydzień, 55\% osób ogląda zaś każdego dnia. Szacuje się, że wideo będzie stanowić 74\% całego ruchu online w 2017 r.

${ }^{21}$ https://www.brandwatch.com/blog/96-amazing-social-media-statistics-and-facts-for-2016/ [dostęp: 20.01.2018]. 
Z kolei Google przetwarza 100 miliardów zapytań miesięcznie. To średnio 40000 zapytań na sekundę. Blisko 91,47\% wszystkich wyszukiwań w Internecie przeprowadzanych jest przez Google. Internetowe zapytania są stawiane przez 1,17 miliarda unikalnych użytkowników. Google odpowiedział na 450 miliardów unikalnych zapytań od 2003 r. Około 60\% wyszukiwań Google pochodzi z urządzeń mobilnych. Do 2014 r. Google zindeksował ponad 130 trylionów stron internetowych.

Natomiast 500 milionów ludzi odwiedza Twittera każdego miesiąca bez logowania. Istnieje łącznie 1,3 miliarda kont, ale tylko 328 milionów jest aktywnych. Każdego dnia wysyłanych jest 500 milionów tweetów.

Ludzie oglądają każdego dnia około miliard godzin filmów na kanale YouTube. Więcej niż połowa wyświetleń w YouTube pochodzi z urządzeń mobilnych. Średnia sesja przeglądania mobilnego trwa dłużej niż 40 minut. Film z największą liczbą wyświetleń to klip do utworu Luisa Fonsiego Despacito, który ma 4,36 miliarda wyświetleń. YouTube generuje około 1148 miliardów wyświetleń filmów na komórki dziennie. W 2014 r. najczęściej wyszukiwanym terminem była „muzyka”, drugim - „Minecraft”.

Kiedy Instagram wprowadził możliwość publikacji filmów, ponad 5 milionów zostało udostępnionych w ciągu 24 godzin. Pizza jest najpopularniejszym jedzeniem na Instagramie. Około 24\% amerykańskich nastolatków podaje Instagram jako swoją ulubioną sieć społecznościową ${ }^{22}$.

Najpopularniejsze serwisy społecznościowe różnią się znacznie pod względem wykorzystania i lokalizacji, w jakich się je używa. Zrozumienie tych różnic w popularności poszczególnych sieci społecznościowych jest bardzo ważne pod względem kierowania treści na określonych odbiorców. Porównując najpopularniejsze sieci społecznościowe, najlepiej przejrzeć je pod kątem aktywnego wykorzystania konta, a nie tylko liczby kont użytkowników ${ }^{23}$. Facebook posiada $18 \%$ udziału na rynku social media, o 7\% więcej niż jego największy konkurent, WhatsApp. Inne ważne podmioty to QQ (9\%), WeChat (8\%) i Qzone (7\%) z ponad 600 milionami aktywnych użytkowników. Grupa głównie zachodnich sieci mediów społecznościowych to Tumblr (6\%), Instagram (4\%) i Twitter (4\%). Facebook zachowuje olbrzymią przewagę nad konkurencją również wśród użytkowników z USA (najbardziej zaawansowany rynek główny, a tym samym dobry poplecznik dla przyszłych światowych trendów).

Każdy marketer ma ograniczony czas działania w mediach społecznościowych, więc powinien określić, na jaką sieć społecznościową skupić swoją uwagę.

${ }^{22}$ https://www.smartinsights.com/social-media-marketing/social-media-strategy/new-global-social-media-research/ [dostęp: 20.01.2018].

${ }^{23}$ Tamże. 
Kolejnym czynnikiem decydującym o czasie, który wpływa na marketing w mediach społecznościowych, jest zaangażowanie publiczności. Statystyki dotyczące wykorzystania i wzrostu w sieciach społecznościowych są dostępne w Globalnym Indeksie Internetowym (GWI). Jest to wiarygodne źródło danych w statystykach mediów społecznościowych, służy między innymi do tego, aby porównać wykorzystanie i zaangażowanie konsumentów w różnych sieciach społecznościowych. Badania są przeprowadzane w cyklach kwartalnych, z których każdy ma globalną liczebność ponad 40000 internautów.

Wiele programów badawczych w mediach społecznościowych nie jest już aktywnych. Chociaż Global WebIndex jest płatną usługą subskrypcji, ich blog zawiera przydatne informacje na temat zachowań konsumentów w Internecie, a Global Web Index Slideshare zamieszcza najnowsze podsumowania danych statystycznych. Region Azji i Pacyfiku generuje większość tego wzrostu, należy zwrócić szczególną uwagę na zaangażowanie rynków wschodnioazjatyckich i południowoazjatyckich. Technologia cyfrowa oferuje nowe możliwości docierania do tych osób, chociaż jak zwykle różnice kulturowe stanowią poważne wyzwanie dla międzynarodowych marketerów. Sieci społecznościowe są najbardziej popularne w takich krajach, jak: Indonezja, Filipiny, Meksyk, Indie i Brazylia (znajdują się w pierwszej dziesiątce, przewyższając USA, Wielką Brytanię i kraje europejskie) ${ }^{24}$.

Około 29\% użytkowników smartfonów korzysta z ogólnych aplikacji służących do obsługi wiadomości, takich jak Whatsapp, Viber lub Kik. Facebook testuje nowe metody reklamy za pośrednictwem komunikatora, a klienci wymagają wyższego poziomu obsługi. Przewiduje się, że coraz więcej marek będzie wykorzystywać reklamy i aplikacje do przesyłania wiadomości w $2018 \mathrm{r}^{25}$

\section{Podsumowanie}

Portale społecznościowe są bez wątpienia skutecznym narzędziem public relations i promocji. Zasięg informacji rozsyłanych przez Internet jest zdecydowanie większy od tych, które powiela się za pomocą tradycyjnych form promocji czy komunikatów medialnych. Sam skrót WWW jest akronimem, który świadczy o ogólnoświatowym zasięgu komunikatów internetowych. Jedyną barierą mogą być tu bariery językowe lub kulturowe. Szybkość przesyłu danych i dynamika mediów społecznościowych odgrywają także dużą rolę, ponieważ rozprzestrzenianie się

${ }^{24}$ https://www.smartinsights.com/social-media-marketing/social-media-strategy/new-global-social-media-research/ [dostęp: 20.01.2018].

${ }^{25} \mathrm{http} / /$ www.wordstream.com/blog/ws/2017/01/05/social-media-marketing-statistics [dostęp: 20.01.2018]. 
informacji w Internecie odbywa się nie tylko przez nadawców komunikatów, ale także przez ich odbiorców, którzy stają się nadawcami. Należy także wspomnieć o kosztach związanych z przekazywaniem informacji, są one zdecydowanie niższe niż podczas wykorzystywania mediów tradycyjnych. Dostępność Internetu oraz liczba użytkowników korzystających z social media stale rośnie, stając się powoli dominującą formą komunikacji międzyludzkiej na świecie. Nie tylko rozwój Internetu jako komunikacji za pomocą komputerów, ale także dynamiczny rozwój technologii mobilnej sprawiają, iż to kanał komunikacji elektronicznej jest najskuteczniejszym i najdynamiczniej rozwijającym się medium. Ważnym aspektem jest także niski stopień ograniczeń w Internecie, co sprzyja kreatywności i rozwojowi. Te cechy sprawiają, iż promocja i ogólnie działania PR za pomocą sieci społecznościowych są bardzo skuteczne i atrakcyjne dla nadawców.

\section{BIBLIOGRAFIA}

Bolter J., Komputer: maszyna i narzędzie, [w:] Nowe media w komunikacji społecznej XX wieku, red. M. Hopfinger, Warszawa 2005.

Gajda J., Juszczyk S., Edukacja medialna, Toruń 2004.

Hills W., Superkomputery i ewolucja, [w:] Nowe media $w$ komunikacji społecznej XX wieku, red. M. Hopfinger, Warszawa 2005.

Kotler P., Marketing, Warszawa 1994.

Kramer T., Podstawy marketingu, Warszawa 2003.

McQuaid D., Teoria komunikowania masowego, Warszawa 2012.

Michalski E., Marketing, Warszawa 2004.

Mruk H., Podstawy marketingu, Poznań 1999.

Pisarek W., Słownik terminologii medialnej, Kraków 2006.

Pokrzycka L., Promocja i public relations $w$ społeczeństwie informacyjnym, Studia przypadków, Lublin 2011.

Szpunar M., Społeczna przestrzeń internetu. Internet jako medium komunikacji społecznej, [w:] Media - komunikacja - zdrowie. Wyzwania - szanse zagrożenia, red. B. Aouli, Torun 2008.

Netografia:

https://www.brandwatch.com/blog/96-amazing-social-media-statistics-and-facts-for-2016.

https://www.smartinsights.com/social-media-marketing/social-media-strategy/ new-global-social-media-research/. 
http://www.wordstream.com/blog/ws/2017/01/05/social-media-marketing-statistics.

https://www.bluecorona.com/blog/social-media-statistics-2017.

https://www.socialbakers.com/statistics/.

https://sproutsocial.com/insights/social-media-statistics/.

https://smallbiztrends.com/2016/11/social-media-statistics-2016.html.

https://www.statista.com/statistics/433871/daily-social-media-usage-worldwide/. https://wearesocial.com/special-reports/digital-in-2017-global-overview https://oursocialtimes.com/7-social-media-statistics-for-2017/. 